\title{
Berle and Means revisited: The governance and power of large U.S. corporations
}

\author{
MARK S. MIZRUCHI \\ University of Michigan
}

\begin{abstract}
In The Modern Corporation and Private Property (1932), Berle and Means warned of the concentration of economic power brought on by the rise of the large corporation and the emergence of a powerful class of professional managers, insulated from the pressure not only of stockholders, but of the larger public as well. In the tradition of Thomas Jefferson, Berle and Means warned that the ascendance of management control and unchecked corporate power had potentially serious consequences for the democratic character of the United States. Social scientists who drew on Berle and Means in subsequent decades presented a far more benign interpretation of the rise of managerialism, however. For them, the separation of ownership from control actually led to an increased level of democratization in the society as a whole. Beginning in the late 1960s, sociologists and other social scientists rekindled the debate over ownership and control, culminating in a series of rigorous empirical studies on the nature of corporate power in American society. In recent years, however, sociologists have largely abandoned the topic, ceding it to finance economists, legal scholars, and corporate strategy researchers. In this article, I provide a brief history of the sociological and finance/legal/strategy debates over corporate ownership and control. I discuss some of the similarities between the two streams of thought, and I discuss the reasons that the issue was of such significance sociologically. I then argue that by neglecting this topic in recent years, sociologists have failed to contribute to an understanding of some of the key issues in contemporary business behavior. I provide brief reviews of four loosely developed current perspectives and then present an argument of my own about the changing nature of the U.S. corporate elite over the past three decades. I conclude with a call for sociologists to refocus their attention on an issue that, however fruitfully handled by scholars in other fields, cries out for sociological analysis.
\end{abstract}

The field now known as corporate governance dates back to Berle and Means's classic work, The Modern Corporation and Private Property. ${ }^{1}$ Interpretations of this work have gone through several waves, but virtually all commentators have acknowledged Berle and Means's basic concern: the separation of ownership from control in large U.S. corporations. Current scholars in the corporate governance area hail mostly from the fields of finance and law, with a smaller number from organizational theory and corporate strategy. Although sociologists paid 
considerable attention to this issue from the end of World War II through the early-1990s, few of them address the topic today. I argue that sociologists' neglect of this topic in recent years has prevented the field from considering a range of important issues. My goal in this article is to describe the primary sociological treatments of the issue of corporate ownership and control, to compare them with treatments by economists and legal scholars, and to suggest ways in which attention to this area would allow us to address important questions regarding the nature and extent of corporate political power.

Before proceeding, I note that my focus is primarily on the United States. There are two reasons for this. First, although there is considerable variation in ownership and control patterns across industrialized nations, the United States is nearly alone in the extent of the dispersal of its stockholders. ${ }^{2}$ Ownership remains highly concentrated and, arguably, fused with control, in nations such as France, Germany, Japan, and South Korea. Second, to do justice to the richness of the crossnational variation while dealing with the theoretical issues that I am concerned with would likely require a book-length treatment. ${ }^{3}$ At the same time, it is important to note that many of the implications about ownership and control in the United States have also been posited to have occurred elsewhere, including Britain, France, and Germany. ${ }^{4}$ The theoretical issues at the heart of this discussion are thus relevant to virtually all industrialized capitalist nations, regardless of the extent to which they have experienced a separation of ownership from control. $^{5}$

I begin, then, with a brief discussion of Berle and Means, focusing in particular on the relevance of this work for debates in sociological theory. I then describe various interpretations and uses of Berle and Means by sociologists during the period 1950-1990. Following this discussion, I examine Berle and Means's views on the role of the board of directors - a critical issue in the debate over corporate control and the ways in which these views were selectively, and misleadingly, interpreted by later theorists. I then discuss more recent work in finance and law, showing the similarities and differences between this work and sociological work that developed concurrently, and in most cases independently. Finally, I examine the evidence on corporate control, both before and since the major changes of the 1980s. I conclude with a discussion of how one can use renewed attention to this topic to address significant questions concerning the structure and political power of corporate elites. 


\section{Background}

The Modern Corporation and Private Property appeared in the early stages of the Great Depression, but it was more a product of the 1920s, or more generally, the period after 1890 that culminated in the stock market crash of 1929. Although the book is best known for the authors' focus on ownership and control, that topic represents only one component of their discussion. Berle and Means began by arguing that capital in the United States had become heavily concentrated during the previous few decades and that this vested a relatively small number of companies with enormous power. As these firms grew, it became increasingly difficult for the original owners to maintain their majority stockholdings, and stocks became dispersed among a large number of small shareholders. The consequence of this dispersal, Berle and Means suggested, was the usurpation, by default, of power by the firm's managers, those who ran the day-to-day affairs of the firm. These managers were seen as having interests not necessarily in line with those of the stockholders. Whereas owners preferred that profits be returned to them in the form of dividends, for example, managers preferred either to reinvest the profits or, in more sinister interpretations, to further their own privileges, in the form of higher salaries or "perks." Removed from the pressures of stockholders, managers, for Berle and Means, were now viewed as a self-perpetuating oligarchy, unaccountable to the owners whom they were expected to represent. In an examination of the 200 largest U.S. non-financial corporations in 1929 , Berle and Means found that 44 percent of them had no individual ownership interest with as much as 20 percent of the stock, a share that they viewed as an approximate minimum necessary for control. Berle and Means classified these 88 firms, which accounted for 58 percent of the total assets among the top 200, as management controlled. In only 11 percent of the firms did the largest owner hold a majority of the firm's shares.

Berle and Means's concern about the separation of ownership from control was not only about managers' lack of accountability to investors. It was also a concern about managers' lack of accountability to society in general. Berle and Means thus wrote of a small group, sitting at the head of enormous organizations, with the power to build, and destroy, communities, to generate great productivity and wealth, but also to control the distribution of that wealth, without regard for those who elected them (the stockholders) or those who depended on them (the larger public). This was hardly a cause for celebration, and Berle and 
Means, in the tradition of Thomas Jefferson, expressed considerable concern about this development.

Many postwar sociologists adopted a very different interpretation of Berle and Means, however. In these works, authored by commentators such as Daniel Bell, Ralf Dahrendorf, and even Talcott Parsons, the separation of ownership from control was actually a harbinger of increased democracy. ${ }^{6}$ If Berle and Means implied that even elected officials (the board of directors) could be far removed from and unaccountable to their voters (the stockholders), this would seem to raise similar concerns about the extent of democracy in the political system. Indeed, to some thinkers, including Joseph Schumpeter and Seymour Martin Lipset, it did. ${ }^{7}$ But most sociologists who wrote on the topic preferred an alternative interpretation: the separation of ownership from control actually contributed to the spread of democracy. To explain how and why sociologists reached this conclusion, some historical digression is necessary.

The period in the United States between the mid-1890s and about 1920 is often referred to as the "era of finance capital." Many of the great trusts, combinations of large numbers of firms that were combined into huge corporations, were formed in the 1895-1904 period. Prototypical examples included U.S. Steel and International Harvester, both of which J.P. Morgan formed and controlled. Rudolf Hilferding wrote about the dominant position of German banks at the turn of the twentieth century. ${ }^{8}$ A number of American commentators, from government officials, including the Pujo Committee of the U.S. Congress and Supreme Court Justice Louis Brandeis, to muckraking journalists such as Ida Tarbell and financial writers such as Alexander Noyes, made similar assessments of the United States at the time. ${ }^{9}$ The United States, in these arguments, was dominated by a small group of financiers and major industrialists, often working in groups, through investment banks, commercial banks, and insurance companies. These groups, the most prominent of which were led by Morgan (with his ally George F. Baker) and Rockefeller (with his ally James Stillman), were viewed as dominating the business world and forging the makings of a "ruling class," ascendant both economically and politically. This view of that period is no longer as unanimous as it once was, as Mark Roe's work indicates. ${ }^{10}$ Yet, it informed virtually all sociological writings on the topic in the period up to the early 1970s. 
Where disagreement occurred was over what happened after this period, from about 1920. Most sociologists believed that the separation of ownership from control led, as Dahrendorf put it, to the "decomposition of capital." " In Riesman's words, "the captain of industry no longer runs business" and thus "no longer runs politics." 12 Echoing this view, Bell suggested that " $[\mathrm{n}] \mathrm{o}$ longer are there America's 'Sixty Families' [the title of a popular book from the 1930s] ... The chief consequence, politically, is the breakup of the ruling class." 13 In Dahrendorf's words, the business community in industrialized capitalist countries (in which he included Britain, France, and Germany as well as the United States) had become "a plurality of partly agreed, partly competing, partly simply different groups."14 These authors thus conceded that something akin to a dominant capitalist class existed in the United States in the early years of the last century but that because of the separation of ownership from control, this class had dispersed, unable to realize itself as a unified block. Because, in the Berle and Means view, the owners of capital no longer controlled their enterprises and those who controlled did not own, Dahrendorf went so far as to claim that we had transcended capitalism altogether. He referred to this presumably new system as "post-capitalist" society.

Rather than sharing Berle and Means's suspicion of managerialism as ushering in a dangerous era of concentrated economic power, American sociologists and other social scientists thus praised the new system as a further extension of democracy. This was reflected in statements about "peoples' capitalism," in which the widespread dispersal of stockholdings meant that corporations were, for practical purposes, publicly controlled, as well as in formulations about the "soulful corporation," concerned as much about its position as a respected member of the community as with its pursuit of profit. ${ }^{15}$ In fact, the pursuit of profit was deemed no longer necessary, as great size, market power, and weak and disorganized stockholders allowed corporate managers to pursue goals other than profits, including sales, growth, or a combination of factors. ${ }^{16}$ Corporate managers, freed from the dictates of stockholders (as well as bankers and other outside forces), were stripped of the entrepreneurial spirit, transforming instead to bureaucratic "organization men." To quote Dahrendorf once again, "[n]ever has the imputation of a profit motive been further from the real motives of men than it is for modern bureaucratic managers." 17 Ownership of capital no longer mattered even for understanding peoples' life chances. In discussing why they chose to focus their study on occupational status 
attainment rather than class, in either a Marxist or Weberian sense, Blau and Duncan suggested that class, "defined in terms of economic resources and interests ..., is no longer adequate for differentiating ... [those] in control of the large capitalistic enterprises from those subject to their control because the controlling managers of the largest firms today are themselves employees of corporations." 18

\section{Rumblings among economists}

Despite its prominence in certain areas of the field, managerialism never had a major impact on neoclassical economics. The reasons for this are straightforward. In neoclassical theory, the firm is a unitary actor that responds to the market. Who controls the firm internally is irrelevant in this view, because market processes ensure unanimity of responses. For all of managerialists' assertions that profit maximization was no longer necessarily a goal of firms, they mustered precious little evidence to support their claims. This lack of evidence made their claims relatively easy to ignore.

In the 1960s, a group of economists began to devise tests of the managerialist thesis. Based on the idea that the motives of corporate decision makers would be reflected in firm performance, these researchers classified firms as either owner or management controlled, and then compared the profit rates of the firms in each group. If, as managerialists suggested, management controlled firms were less profit oriented than were owner controlled firms, then, these scholars reasoned, the former should show lower profit rates than the latter. This premise may be questionable, since it assumes an unproblematic link between motive and performance when in fact different types of firms may face different kinds of obstacles. On its own terms, however, the evidence at best provided lukewarm support for the managerialist thesis. Although Monsen, Chiu, and Cooley and Palmer found some tendency for owner controlled firms to earn higher profits than management controlled firms, Kamerschen found no such effect, and the differences found in the first two studies were quite small. ${ }^{19}$ In the most comprehensive study on the topic, Larner found only negligible differences - slightly higher profits among the owner controlled firms, but differences of little substantive significance. ${ }^{20}$

Other findings were even less kind to managerialism. In a study of chief executive firings among the 500 largest U.S. manufacturers in 1965, 
James and Soref found that the strongest predictor of dismissals was the extent to which the firm's profits had declined in the previous year. ${ }^{21}$ Whether the firm was owner or management controlled had no significant effect. A second major component of the managerialist thesis was that managerial autonomy increased as a result of increases in retained earnings, which freed managers from dependence on banks and other financial institutions for capital. A study by Lintner indicated that in the three decades (1925-1955) after Berle and Means's study, there was virtually no decline in the proportional use of external financing by U.S. corporations. ${ }^{22}$ In a later study on the topic, Stearns showed that the use of external financing as a percentage of total financing fluctuated between 1946 and 1982, staying at relatively low levels during the 1950 s and early 1960 s but then rising consistently and significantly beginning in $1966 .{ }^{23}$

Although some economists raised questions about the behavioral implications of the managerialist thesis, the approach did attract considerable attention, and even support, from two emerging branches of the field: transaction cost economics and agency theory (although the latter was more equivocal). Oliver Williamson, the leading contemporary proponent of transaction cost economics, used Herbert Simon's bounded rationality assumption to develop a model in which managerial goals, of which profit maximization was just one, could vary across conditions. ${ }^{24}$ In his subsequent work, Williamson drew in part on the historical analyses of Alfred Chandler to show the importance of managerial decision making. ${ }^{25}$ The decision to internalize production or distribution or to rely externally on markets is predicated on the assumption of managerial discretion - that managers have the power to make these decisions. The title of Chandler's subsequent book, The Visible Hand, was an explicit acknowledgement of the active role of management in directing the firm. ${ }^{26}$

If the transaction cost approach was based on the assumption of managerial discretion, a model developed around the same time, agency theory, took the degree of managerial autonomy as far more problematic. More than any approach, agency theory has focused on the complexities and difficulties of monitoring that arise when ownership is widely dispersed. Although this approach has now spawned hundreds, if not thousands, of articles, my purpose here is to touch on some of its key theoretical points. To do this I focus on two of the most important works within this perspective, the articles by Jensen and Meckling and Fama and Jensen. ${ }^{27}$ 
Agency theory is in many respects a critique of managerialism. Its proponents acknowledge the difficulties that emerge with the dispersal of stockholdings and the rise of management, but they want to address them within the framework of more conventional economic theory. Jensen and Meckling begin by distancing themselves from some key managerialist claims, in particular the rejection of the profit maximization assumption. They acknowledge that managers might have motives that differ from those of owners, and they admit that monitoring these managers under conditions of wide stock dispersal can be difficult. The issue, then, is to create an "alignment of incentives," in which managers' interests will correspond with those of owners. Much of the discussion for both Jensen and Meckling and Fama and Jensen involves means by which owners can provide effective monitoring mechanisms. Much of the research within the area involves examinations of the effectiveness of these various mechanisms. One mechanism proposed by the authors is the provision of equity to management. When managers own stock in the firm, they share interests in its performance with the remaining equity holders. Another important mechanism is to provide direct monitoring through the appointment of an expert board of directors, who are constrained to operate in the stockholders' interest because of their need to maintain their reputations. A third monitor is the market, both in terms of its effect on the firm's stock price and the related market for corporate control. This last approach is potentially the most threatening, since it raises the possibility that managers could be ousted.

Each of these approaches has a potential downside from the perspective of owners. When managers own stock they divert some of the equity of the firm to themselves, thus diluting the value of the remaining owners' equity. Board members, regardless of their reputation, still need to be monitored, which could be difficult if stockholders are widely dispersed. And takeovers can be disruptive, and generally occur only after the firm's equity has become devalued, a situation that owners are unlikely to welcome.

\section{Rumblings among sociologists}

For nearly four decades after the publication of Berle and Means's classic study, social scientists who wrote on the topic almost unanimously accepted Berle and Means's analysis. This does not mean that 
all social scientists agreed with Berle and Means. As I have shown, neoclassical economists basically ignored the issue and assumed an unproblematic link between ownership and control. But those social scientists who addressed the topic were overwhelmingly in agreement with Berle and Means, although there were some differences among them on the implications of Berle and Means's findings. Two prominent Marxist economists, Baran and Sweezy, for example, went to great lengths to defend Berle and Means's empirical findings but with equal vehemence denied that the separation of ownership from control had any implications for corporate behavior. ${ }^{28}$ With the exception of a highly polemical study by another Marxist economist, Victor Perlo, there were virtually no published critiques of managerialism between 1932 and $1970 .{ }^{29}$ Slowly, however, sociologists and other critics began to raise questions about managerialism.

One of the first such works was an article by a prominent sociologist, Mayer Zald, who argued that the board of directors played a prominent role in monitoring corporate management. ${ }^{30}$ Zald exhorted sociologists, who had virtually ignored this topic, to pay more attention to it. Zald's article, along with a study by an economist, Peter Dooley, was among the earliest works to raise questions about management control. ${ }^{31}$ A study by political scientist Philip Burch, which questioned the extent of management control, was also influential. ${ }^{32}$ But the breakthrough piece of sociological critique was a 1974 article by Maurice Zeitlin. $^{33}$

Zeitlin's primary dispute was with the evidence on stock dispersal. Returning to Berle and Means's analysis, Zeitlin showed that nearly half of the corporations that Berle and Means had classified as management controlled simply had "no identified center of control," that is, Berle and Means were unable to locate a single stockholder with an interest as large as 20 percent (their cutpoint for minority owner control) and were unable to conclusively state that the firms were management controlled. Zeitlin thus suggested that no more than 23 percent of Berle and Means's firms (the 200 largest U.S. non-financials) were, by their criteria, clearly management controlled. Even if one accepted Zeitlin's critique of Berle and Means, one could argue that the more recent findings presented by Larner demonstrated conclusively the degree of stock dispersal. Using a more stringent criterion for management control, a largest holding of only 10 percent, Larner found that more than 80 percent of the 500 largest U.S. manufacturers as of 1964 had no 
individual interest with a holding of more than 10 percent.$^{34}$ Regardless of Berle and Means's findings, this suggested that by the mid-1960s, the managerial revolution was, as Larner put it, "close to complete." Zeitlin proceeded to criticize Larner's findings as well, however, using material from an article in Fortune, in which the author suggested that several of the firms classified by Larner as management controlled were in fact owner controlled. ${ }^{35}$ On this basis, as well as a reanalysis of Larner's data, Zeitlin argued that 40 percent or more of Larner's firms were owner controlled. Zeitlin also suggested that the quantitative techniques used by Berle and Means and subsequent authors may have missed a significant number of firms that were in fact owner controlled but had no publicly identifiable large stockholder. Using Burch's findings, based on a detailed reading of the business press, Zeitlin argued that as many as 60 percent or more of the largest U.S. firms may have been owner controlled at the time.

Around this time, some authors were also pointing to the potential power of large commercial banks. Concern about the banks, as I have noted, dated back to the early part of the twentieth century. Between the publication of Berle and Means's book and the late-1960s, researchers paid virtually no attention to this issue, however. As early as the 1940s, Marxist economist Paul Sweezy had described "the decline of the investment banker," and except for Perlo, not even Marxists were writing about commercial banks. ${ }^{36}$ Instead, the banks were viewed as intermediaries, whose role differed little from those of accountants and lawyers. During the 1960s in the United States, a Congressional investigation chaired by Representative Wright Patman examined the stockholdings of commercial bank trust departments. Commercial banks in the United States are not allowed to directly own stocks in non-financial corporations. Their trust departments manage pension funds for other firms, however, and they invest in the stock of other firms, stock on which they have voting rights. The role of institutional investors became a major public issue during the $1990 \mathrm{~s}$, but concerns about it go back several decades. ${ }^{37}$ The Patman committee found that about 30 percent of the 500 largest U.S. manufacturers in 1967 had at least five percent of their stock held by a commercial bank trust department. Drawing on this finding and additional data on institutional holdings, David Kotz argued that as many as 40 percent of the 200 largest U.S. nonfinancial corporations could be said to be controlled by a bank. ${ }^{38}$ The potential power of banks finally gained attention in sociology through a major project directed by Michael Schwartz, who approached the problem 
of corporate control in a very different way from others involved in this debate, a way that ironically corresponded in a number of ways with the agency theory approach that was developing concurrently. I discuss this project in the following section, but before doing so, it is necessary to address an important, and overlooked, implication of Berle and Means's argument.

Beginning with Berle and Means, corporate control had been addressed at the level of the firm. Although Berle and Means were sensitive to the fact that corporate managers faced pressures from groups other than stockholders, their empirical analysis focused almost entirely on stockholdings. Firms were classified into one of five categories based on the size of their largest identifiable ownership share. We must reemphasize that Berle and Means were well aware that their scheme was arbitrary, that control could be exercised in a number of ways, including by outsiders such as bankers. As they noted, "Occasionally a measure of control is exercised not through the selection of directors, but through dictation to the management, as where a bank determines the policy of a corporation seriously indebted to it." ${ }^{39}$ Again, however, in examining the condition of large corporations in general, Berle and Means treated control at the level of the individual firm.

Those who later tested Berle and Means's argument, whether supportive or critical, maintained the same approach. Whether it was Larner demonstrating the "near completeness" of the managerial revolution, Burch arguing for the persistence of family control, or even Kotz suggesting the possibility of bank control, these approaches all involved setting a percentage threshold at which the size of a stockholding was deemed sufficient to ensure control, identifying the largest stockholder, and then tabulating the number of firms in which this stockholder exceeded the threshold. The largest firms were classified as 80 percent management controlled, 60 percent family controlled, or 40 percent bank controlled, but there was little recognition or acknowledgement of the possibility that firms might be embedded in a network consisting of other firms, whose behaviors might have considerable influence on them.

Zeitlin was particularly concerned with this issue. Corporations, in his view, were not necessarily independent entities but instead could be viewed as tools of individuals or family groups who used them to accumulate capital. If this were the case, he argued, then control 
might be located not with the insiders who ran the day-to-day affairs of the firm, or even necessarily with large individual stockholders, but rather with families, financial institutions, or groups of other firms. Zeitlin and Ratcliff attempted to illustrate this thesis with a study of corporate control in Chile, in which they found that a detailed examination of family ownership and kinship ties provided a more valid portrait of control relations than did application of the Berle and Means criterion..$^{40}$ Lewis Corey had recognized a similar point in discussing the basis of J.P. Morgan's control at the turn of the twentieth century. As Corey put it, "The House of Morgan and other financial masters did not own the corporations under their control. Nor was ownership necessary. Stockholders being scattered and numerous, control was easily usurped by minority interests, particularly when these interests were institutionalized in the formidable combination of the House of Morgan." ${ }^{41}$ Rather than being based on the purely legal criterion of stock ownership, Corey suggested that Morgan's control was based on a complex system of relationships, including "stock ownership, voting trusts, financial pressure, interlocking of financial institutions and industrial corporations by means of interlocking directorates, and the community of control of minority interests." ${ }^{42}$

What is especially interesting about this view is its convergence with Berle and Means on the one hand, and agency theory on the other. Whereas Zeitlin and other critics of managerialism focused on showing that stockholdings had not dispersed to the extent that managerialists had claimed, Corey suggested that the separation of ownership from control was precisely what was necessary for financiers such as Morgan to dominate. Berle and Means were concerned that stock dispersal would place power in a small group, unaccountable not only to stockholders but also to larger constituencies. Corey's description of Morgan's power is strikingly similar. Where Berle and Means and Corey differed was in their view of who filled this vacuum. For Berle and Means, it was the managers, those insiders who ran the firm on a daily basis. For Corey, it was leading finance capitalists, tied to major financial institutions whose control spanned several corporations simultaneously. As I shall argue below, these two views may be more similar than people realize. Before addressing that issue, however, I want to note the similarity between Corey's description and the more recent versions of agency theory. As Davis and Useem have noted, monitoring mechanisms within this model are now best viewed as an "ensemble," of which there are several different approaches. ${ }^{43}$ Agency 
theorists continue to focus heavily on the equity market (note that Corey also acknowledges stock ownership as an important basis of control), but they also focus on such factors as the appointment of expert board members and, increasingly, the role of banks and other external entities. ${ }^{44}$

To return to Berle and Means, two points are worth mentioning. First, as we have seen, Berle and Means were more aware of the potential for external control by principals other than stockholders than is normally acknowledged. More important, though, is to understand exactly to whom Berle and Means were referring when they spoke of managers. Corporations in the United States include, by law, a board of directors consisting of at least three members, and a senior management consisting of the chief executive and other leading officers. In joint-stock companies, the board is elected by the stockholders, who then appoint the CEO. Most current descriptions treat the board and management as separate groups. Managers are normally assumed to consist of the CEO and other leading officers of the firm. The CEO and several other top officers usually sit on the board as well. They are referred to as inside directors. But the board also consists of people whose primary affiliations are with other units, including other firms. Because the other inside directors are normally subordinates of the CEO, the outside directors take on a particularly important role, since they are the only board members whose formal authority is exclusively above that of the CEO.

Although most contemporary observers distinguish between the board and management, Berle and Means did not. For Berle and Means, "managers consist of a board of directors and the senior officers of the corporation." 45 To be sure, in legal terms, the board is not an independent entity. As Berle and Means put it, "Since direction of the activities of the corporation is exercised through the board of directors, we may say for practical purposes that control lies in the hands of the individual or group who have the actual power to select the board of directors ..." ${ }^{46}$ Note, however, that for Berle and Means, the board (1) is a component of what they call management and (2) directs the activities of the corporation. Because their key point about the separation of ownership from control is that managers become a self-perpetuating oligarchy, this means that it is the board, and not simply the officers, whom Berle and Means view as in control of the firm. Simply because Berle and Means held this view does not mean that is correct, of course. It is entirely possible that the managers have usurped power from the 
board in the same way that the board took power from the stockholders. This has in fact been the dominant view among those who have studied board-management relations. For the moment, though, let us assume that Berle and Means were correct, and address the implications of their view.

\section{Directors and relations among firms}

The outside directors of large U.S. firms tend to be officers of other leading firms. They may represent leading customers or suppliers, or consist of bankers, lawyers, or accountants who provide legal or financial advice, or simply friends or trusted allies of the CEO. When members of the board of one corporation sit on the board of the other, the tie they create is referred to as an interlocking directorate, or an interlock. The existence of interlocks has been the source of both interest and concern for at least a century.

Much has been written about interlocks, and there is little need here to add to this huge literature. ${ }^{47}$ It may be worthwhile to specify why they have been important to study, however. We saw earlier that a major consequence of the managerial revolution was assumed to be the dispersal of power among the leading capitalists and financiers of the early twentieth century. Interlocks were seen by many observers as a crucial indicator of this concentrated power. Perhaps the most famous statement was provided by Justice Louis Brandeis of the U.S. Supreme Court in his classic book, Other Peoples' Money. ${ }^{48}$ Drawing on the findings of the Pujo Committee, Brandeis recounted the large number of connections among major banks and leading railroads and industrial firms. He then issued his now-famous quote:

The practice of interlocking directorates is the root of many evils. It offends laws human and divine. Applied to rival corporations, it tends to the suppression of competition and violation of the Sherman law ${ }^{49}$ Applied to corporations which deal with each other, it tends to disloyalty and to violation of the fundamental law that no man can serve two masters ... It is the most potent instrument of the Money Trust. Break the control so exercised by the investment bankers over railroads, public-service and industrial corporations, over banks, life insurance and trust companies, and a long step will have been taken toward attainment of the New Freedom. ${ }^{50}$

Two things are worth noting in this passage. First, interlocks are seen as creating problems for the efficient working of the market economy. Ties among competitors (which were outlawed in the Clayton Act of 
1914, adopted shortly after Brandeis wrote) reduce competition within industries, thus driving up prices, and ties between customers and suppliers create conflicts of interest, in which the board member cannot serve the best interests of one set of stockholders without simultaneously harming the interests of the other. Second, interlocks are both a cause and consequence of the concentration of power in a small elite, a phenomenon that may have serious implications for democracy.

We have now come full circle. Earlier we saw how the separation of ownership from control was used by some sociologists as evidence for the dispersal of power and the spread of democracy. But Corey, in his study of the House of Morgan, noted that the separation of ownership from control actually made it easier for a small group of finance capitalists to exercise power. Brandeis, as did Corey and other writers of the period, suggested that interlocking directorates were one means by which this power was exercised. And sociological managerialists did not dispute the point, at least initially. Instead, they tended simply to ignore the issue, based on the assumption that widespread interlocks were a product of an earlier age. Nearly alone among sociologists of the postwar period (C. Wright Mills, who took a very different position, was another exception), Arnold Rose spoke explicitly to the issue, even stating that "[i]nterlocking directorates, where they occur in the larger corporations, give them a high degree of cohesiveness." 51 This did not pose a problem for Rose, however, because he simultaneously asserted that "interlocking directorates are the exception rather than the rule." 52

The presumed significance of interlocks noted by the critics of corporate power in the early twentieth century, authors of studies by U.S. government agencies in the 1930s and 1950s, and the few sociologists, such as Mills and Rose, who addressed the topic suggested that the phenomenon would be an important one for critics of managerialism to address. ${ }^{53}$ The first sociologist to examine the topic comprehensively was Michael Schwartz, who teamed with a group of students to produce a number of studies. In a series of works, Schwartz and his colleagues demonstrated that nearly all of the largest U.S. corporations were connected into a single network through interlocks. ${ }^{54}$ The most central firms in these networks were primarily the largest commercial banks and insurance companies, suggesting that they played a special role in the business world. ${ }^{55}$ My study, which looked at interlock networks at seven different points between 1904 and 1974, revealed that major financial institutions were the most central firms during the entire 
70-year period. Although the density of the network declined between 1912 and 1935, following passage of the Clayton Act, nearly all of the largest firms remained tied together in a single network.

These studies raised a number of questions. It is now known, for example, that in even random networks of people, individual actors will be able to reach most others within a relatively small number of steps. ${ }^{56}$ Although Mintz and Schwartz provided a number of individual case studies of relations between banks and non-financial firms, and I found strong correlations between the structure of the networks I observed and historical evidence from the early twentieth century, it was unclear whether the connections among the firms reflected the cohesion of the business community, the power of financial institutions, or neither.

There were reasons to believe that centrality in the interlock network was associated with a firm's power. A considerable amount of evidence from network studies suggested such a correlation in other contexts, although more recent work suggests that the relation is more complicated than network analysts originally realized. ${ }^{57}$ One reason to question whether centrality implied power was our limited knowledge about the specific meaning of the interlocks. This limitation in part reflected our lack of knowledge about the nature of corporate boards. Once sociologists began to demonstrate the ubiquity of interlocks, managerialists - no longer able to rely on Rose's assertion that interlocks were rare - altered the basis of their critique. Two factors were now at issue: First, what were the behavioral consequences of interlocks? Did the interlocks that firms maintained lead them to behave differently from the way they would have behaved in their absence? And second, what if directors were not powerful, but instead were merely figureheads, appointed by or at the behest of the CEO, either unwilling or unable to confront management over policy?

Both of these issues were subsequently addressed, but I want to focus first on the role of the board. Berle and Means might have viewed the board as controlling the firm, but they were writing in the early twentieth century. By the time most of the later managerialists were writing, managers had become defined exclusively as the officers of the firm. The board, meanwhile, was now seen as a group of largely passive figureheads, appointed and dominated by the CEO. Examples of this view were plentiful. Myles Mace, in his classic work on boards, for example, suggested that "the powers of control usually rest with 
the president - not with the board ... It is the president who, like the family owner-managers in the small corporation, determines in large part what the board of directors does and does not do." 58

There are a number of reasons that boards over time might have lost power to managers. Although Berle and Means's primary focus was on the dissolution of stock ownership, the growing complexity of the corporation and the consequent need for professional managers was cited by a number of managerialists as a reason for the development of management control in the first place. In the early twentieth century, outside board members frequently represented controlling interests, as when J.P. Morgan personally selected the entire boards of U.S. Steel and International Harvester. But in later years this control was less evident. In my historical analysis, for example, the proportion of interlocks between financial and non-financial corporations that involved officers of the financial firm sitting on the board of the non-financial (as opposed to vice versa) declined from 65.2 percent in 1912 to 46.2 percent in $1974 .{ }^{59}$ The phenomenon of banks placing one of their officers on the board of a non-financial as a means of control seemed to be a thing of the past by the 1960s. ${ }^{60}$ Instead, bank boards became arenas in which representatives of several industries convened, perhaps to discuss conditions in the economy as a whole. ${ }^{61}$ Even those bank officers who sat on non-financial boards appeared as likely to have been invited in an advisory capacity as to have demanded a position as a means of exercising control. And the reasons for this, if true, are not difficult to understand. Corporate CEOs who sit as outside directors on the boards of other firms are full-time employees of their home firms. The amount of commitment and expertise necessary to monitor the CEO of another firm thoroughly may be prohibitive. In addition, having been appointed by someone who is likely to be a friend, there may be few incentives to ask difficult questions or provoke confrontations. The more boards on which an individual sits - and some leading CEOs sit on a halfdozen or more - the less energy one has to monitor the firm carefully. When Lorsch and MacIver asked whether board members were pawns or potentates, the answer from these earlier discussions was clearly the former. ${ }^{62}$

If these views were accurate, then they raised serious questions about the meaning of corporate interlocks. Certainly interlocks might reflect friendship patterns within the corporate elite, as many of Mace's subjects suggested, or they might reflect resource dependence relations 
among customers and suppliers, as theorists such as Pfeffer and Salancik argued. ${ }^{63}$ But the idea that they represented either control relations among firms, or mechanisms of political unity among the corporate elite, seemed increasingly farfetched. ${ }^{64}$ Interlocks, contrary to Arnold Rose, may indeed have been ubiquitous, but this may not have had the meaning that even Rose would have attributed to it.

As compelling as these latter-day managerialist views were, however, they too rested on a thin empirical foundation. In fact, even where evidence of board passivity was abundant, conceptual difficulties in these arguments rendered such passivity difficult to interpret. It was in this context that I developed a critique of the managerialist model of boards. ${ }^{65}$ Interlocking directorates were widespread, and their frequency and pattern seemed consistent with a cohesive corporate community led by major financial institutions. For this view to have any possible credence, however, it was necessary to demonstrate that boards of directors played a meaningful, as opposed to a merely titular, role in corporate governance.

My approach to this problem was to draw on a model of power developed in political sociology and political science. Debates in political science around the concept had culminated in three general positions, only two of which need concern us here. Power may, on one hand, involve the exercise of overt control over another actor, either through direct commands or through victory under conditions of conflict. Political scientists such as Robert Dahl and Nelson Polsby acknowledged that power may at times be difficult to observe, but they insisted that the only way to demonstrate its existence would be to identify instances in which it was observable. The best examples, they suggested, were cases of political issues on which various actors had opposing views. Those whose positions regularly prevailed could be said to have power. ${ }^{66}$

Although there was little disagreement that consistent achievement of one's objectives was indicative of power, critics of Dahl and Polsby argued that power is often far more subtle, and that those aspects in which it is most difficult to observe may be precisely those in which it is most operative. ${ }^{67}$ The issues that never reach the public for discussion because powerful actors were able to keep them off the agenda represent one such example. ${ }^{68}$ Scholars such as Mills argued that the areas of overt conflict were those that had the least significance, and that the major decisions were made by a small, largely unified, group. ${ }^{69}$ 
A similar argument could be made about boards, I suggested. Board members may have less knowledge of the internal workings of the firm than do the top managers. They may make few, if any, decisions over long periods of time, instead essentially "rubber-stamping" the suggestions of the CEO. They may appear to be passive, disinterested, and fully co-opted. And yet none of this necessarily indicates that they lack power. A key variable, I argued, is the financial condition of the firm. Regardless of how active a board is, its members hold the responsibility of both appointing and, if necessary, removing the CEO. It may be that board members appointed after the ascendance of the current CEO are more beholden to him or her and thus less likely to be critical. As one CEO told Mace, however, "if you get a lot of guys from the outside, even though you pick them, you lay yourself open to a takeover deal." ${ }^{170}$ In other words, even directors who are appointed after a CEO assumes his or her position may still find it necessary to remove the CEO if the firm experiences difficulty. Board members who fail to do this make themselves vulnerable to stockholder lawsuits. The prevalence of outside directors, declines in performance, and the threat of lawsuits as well as takeovers, all make the firm's top management potentially vulnerable to the board. When times get tough, we often see the CEO removed. The ouster of General Motors' CEO Robert Stempel in 1992 was viewed in the business press and by many scholars as a stunning event, but evidence reaching back through the 1980s and 1970s ${ }^{71}$ and even into the $1960 \mathrm{~s},{ }^{72}$ not to mention the many well-publicized cases in the early 2000s, suggests that the board stepping in to oust the CEO is far from rare.

The idea that the board was a passive tool of management was therefore an exaggeration, I argued. Although the actual extent of board power clearly varied across firms, the potential and at times necessity to exercise their power was always there, even when it appeared dormant for years at a time. Ironically, this argument, although somewhat different in focus and style, was in substance similar to those implicit in the works of agency theorists. As we saw above, these theorists acknowledged that the board might have difficulty monitoring management under certain conditions. That they found it necessary to mention this, however, suggested that they viewed the board as normally in control. As agency theory made its way into organizational analysis, the view that board members are often more than passive bystanders diffused rapidly. ${ }^{73}$ 


\section{An intriguing convergence}

Shortly after the publication of "Who Controls Whom?," organizational analysts began to focus on the role and behavior of corporate boards. Fredrickson, Hambrick, and Baumrin presented a model of factors that might account for CEO dismissal, several of which involved board structure and behavior. ${ }^{74}$ Baysinger and Hoskisson and Walsh and Seward followed this with models of the conditions under which boards would be most likely to monitor managers. ${ }^{75}$ Fredrickson et al. were concerned primarily with the ways in which board members' values and allegiances affected their likelihood of dismissing a $\mathrm{CEO}$, and they drew primarily on organizational theory to develop their model. Baysinger and Hoskisson and Walsh and Seward drew explicitly on agency theory in establishing a set of contingencies under which boards were most likely to act. Like my piece, these three articles were primarily theoretical. Empirical works had also emerged during this period, however. This literature is large, and much of it is reviewed elsewhere. ${ }^{76}$ But regardless of whether researchers used agency theory, organizational analysis, or more sociological perspectives, this work repeatedly demonstrated that boards of directors had significant effects on firm behavior.

In one such study, Kosnik used agency theory to show that firms with high proportions of outside directors were less likely to engage in "greenmail," the repurchase of company stock at inflated prices, than were firms with high proportions of insiders. She used this finding to suggest that firms with higher proportions of outside directors were more effective. ${ }^{77}$ Cochran, Wood, and Jones and Singh and Harianto found, contrary to expectation, that firms with outsider-dominated boards were more likely to provide golden parachutes (lucrative severance packages) for their CEOs than were insider dominated firms. ${ }^{78}$ Wade, O'Reilly, and Chandratat identified a possible variable to account for this paradoxical finding: whether the outside directors were appointed by the particular CEO. ${ }^{79}$ Wade et al. found that the greater the number of outsiders appointed after the CEO assumed power, the greater the likelihood of a golden parachute package, although this effect held only for management controlled firms. ${ }^{80}$

In addition to work on boards per se, several other researchers have demonstrated that director interlocks have effects on firm behavior. Davis found that adoption of takeover defense plans known as "poison pills" diffused through interlock networks. ${ }^{81}$ Haunschild found that 
firms whose CEOs sat on the boards of firms that had recently engaged in acquisitions were more likely to engage in acquisitions themselves. ${ }^{82}$ I showed that pairs of interlocked firms were more likely than pairs of non-interlocked firms to engage in similar political behavior. ${ }^{83}$ And Palmer found that firms with interlocks with commercial and investment banks were more likely than non-interlocked firms to be the target of friendly, as opposed to hostile, takeover attempts. ${ }^{84}$

Not all of the studies of board structures and interlocks have demonstrated the predicted effects. Contrary to Palmer, Davis and Stout found no association between the presence of a banker on a firm's board and the firm's likelihood of being a takeover target, and Fligstein and Brantley found no association between bank interlocks and merger activity during the 1970s, although in a subsequent study, Fligstein and Markowitz did find such an association during the 1980s. ${ }^{85}$ The clear conclusion from the full corpus of work within this area, however, is that boards of directors, and director ties between firms, have significant effects on a wide range of corporate behaviors.

The growing emphasis on boards among business scholars (and some sociologists) during the 1980s and 1990s reflected the widely held belief that managerial autonomy had declined over the previous two decades. Although this view was largely implicit in most of the research cited above, other scholars were more explicit about the hypothesized decline in managerial discretion, including the possible resurgence of stockholders. I turn to this issue in the following section.

\section{Revolt of the owners, decline of the banks}

As Useem has noted, managers were under increasing pressure from stockholders as we moved into the 1980 s. ${ }^{86}$ The U.S. stock market had performed poorly during the 1970s. Companies were in relatively weak equity positions. In the agency theory view that emerged concurrently with this development, these firms were "undervalued," ripe for takeover by alternative management teams that would "right" the company, thus increasing its stock price. The 1980s seemed to bear out the predictions of the agency model, as nearly one-third of the Fortune 500 received takeover bids during the decade. ${ }^{87}$

Just as managers were becoming increasingly vulnerable, however, an interesting development occurred, slowly at first but gathering steam into the 1990s: the decline of the commercial banks. Before detailing 
600

this development, it is worthwhile to ask exactly what the purported role of the commercial banks was. Early bank control theorists, going back to Hilferding and Lenin, argued that banks, through their control of capital, exerted broad control over nonfinancial corporations ${ }^{88}$ Later proponents of this view believed, to varying degrees, that banks could actually dictate the policies of the firms they controlled. In Kotz's view, this was a result of the banks' ability to vote the stock held by their trust departments. ${ }^{89}$ In Fitch and Oppenheimer's more colorful (albeit less sober) analysis, the banks were willing to suck capital out of the firms they controlled, even if it drove the firms to bankruptcy. ${ }^{90}$ Both of these views were disputed even by other Marxist or Marxist-oriented analysts. Both Sweezy and O'Connor viewed the bank control model as a fiction, an attempt to apply a decades-old argument to a world that had long passed it by. ${ }^{91}$ In a thorough, careful analysis, Herman acknowledged that banks might occasionally exercise control, but argued that such situations were rare. ${ }^{92}$ In Herman's view, management ruled. In fact, in acknowledging the power of managers while at the same time expressing concerns about their lack of accountability, Herman's work stands as the most worthy successor to Berle and Means.

Sensitive to the concerns expressed by Herman and others, Mintz and Schwartz rejected a crude bank control model. ${ }^{93}$ Banks rarely become involved in running particular firms, they argued. Instead, they suggested, the banks exercise a broad level of "hegemony" over nonfinancial firms, able to set the conditions under which these firms operate. Because capital is a universal and highly demanded resource, and because (Mintz and Schwartz claimed) firms were incapable of raising sufficient capital on their own, they depended on the banks, as well as other financial institutions such as insurance companies. Firms were unable to play competing banks off against one another because most of the major financing schemes involved consortia, cooperative relations among the banks, in many cases dozens on the same deal. The banks' views were neutral. They simply allocated capital where they saw the best likely return. To maintain their knowledge of developments across multiple industries, the banks invited the CEOs of a range of leading firms to sit on their boards. These boards thus became meeting places for the leaders of the business community, a kind of economic version of the Business Roundtable. The board of the former Chase Manhattan bank, for example, had no fewer than 14 CEOs of Fortune 500 firms in 1982. This new role of bank boards, which emerged after World War II, explained for Mintz and Schwartz why the direction of bank interlocks 
had changed during the twentieth century from primarily bank officers sitting on non-financial boards to vice versa. Still, the leading banks remained by far the most central firms in the network of interlocking directorates.

As we have seen, agency theorists, although not making any global claims about bank dominance, developed an entirely compatible argument. Just as with equity holders, lending banks had an investment in the firm that required monitoring. Whether by placement of an officer on the borrower's board, voting the stock held by its trust department, or inserting restrictive covenants into its loans, agency theorists viewed banks' need to monitor as an important component of the lending process. ${ }^{94}$ Exactly how large a role bank monitoring, or even stockholder monitoring, played in a general sense remained beyond the scope of those working within this approach, however. This is significant, because just as Mintz and Schwartz's book appeared, and agency theory formulations about the potential power of banks emerged, a change was occurring that would have significant implications for both models.

Beginning in the early 1980s, rapid changes in technology and the regulatory environment led U.S. corporations to reduce their reliance on banks for capital and led individuals to reduce their deposits in commercial banks. Both the number of commercial banks and the proportion of corporate debt acquired from commercial banks declined by one-third between 1979 and $1994 .{ }^{95}$ Large commercial banks responded to the loss of their traditional franchise by changing their focus from lending to financial services, such as capital market services, foreign currency exchange, and derivatives. Although banks faced declining margins on domestic lending, overseas lending, although more risky, promised higher returns. Bank profits, which had declined precipitously in the late 1980s and early 1990s, rebounded by the mid-1990s. This change in bank strategies had the effect of altering the social role of commercial banks within the American business community: as Davis and Mizruchi document, the largest banks substantially reduced the number of executives of major corporations appointed to their boards, thus losing their place at the center of the interlock network.

It appears almost self-evident that leading commercial banks would have shifted their operations overseas during this period. An examination of the evidence suggests otherwise, however. ${ }^{96}$ The tidal shift to overseas operations among major American banks occurred not during 
the 1980s and 1990s but during the 1960s. In the more recent period there has been very little expansion. In fact, the number of U.S. banks operating overseas declined between the early 1980s and 2000, and most of the foreign presence that remains is dominated by two banks, Citigroup and Chase.

The findings described by Davis and Mizruchi have an interesting implication. The evidence of the decline in the power of U.S. commercial banks is quite strong. U.S. non-financials' reliance on the banks for capital has declined significantly. The banks have moved instead to financial services, activities that are profitable but that do not lend themselves to the accumulation of great power. A study, by Stearns and me, of corporate relationship managers in a major commercial bank revealed the typical bank/non-financial relation to be a far cry from anything described by Mintz and Schwartz. ${ }^{97}$ Importantly, however, the fact that the proliferation of alternative sources of capital corresponded with the sharp decline of bank centrality suggests that Mintz and Schwartz may have been correct about the period in which they were writing. Critics cannot have it both ways. Either the banks were in fact powerful into the early 1980 s, or the declines that we observe over the past twenty years are not really significant. Both views may actually have a grain of truth. Davis and Mizruchi suggest that the banks' declining centrality was likely to have been voluntary. ${ }^{98}$ As they shifted from lending to financial services, there may have been less reason to have Fortune 500 CEOs on the board. The banks instead tried to look like investment banks, firms that did not typically play host to non-financial CEOs. This scenario suggests that the banks have not lost their ability to accomplish their economic goals, but that their shift in focus has inadvertently reduced their political power within the business community. We do not know if this is the case. But the fact that we do not know is precisely the problem, and precisely what we need to address.

\section{Who controls, and who cares?}

I began this article with a discussion of Berle and Means, but I wanted to focus on a particular, and neglected, aspect of that classic work: Berle and Means's concerns about the concentration of power. Their views on the concentration of economic power were quite explicit, albeit largely ignored by subsequent interpreters. But embedded in their argument was an equally important concern: the potential concentration 
of political power, an issue prominent in American political thought going back to Thomas Jefferson. In their concluding paragraph, Berle and Means suggested that

The rise of the modern corporation has brought a concentration of economic power which can compete on equal terms with the modern state... Where its own interests are concerned, it even attempts to dominate the state. The future may see the economic organism, now typified by the corporation, not only on an equal plane with the state, but possibly even superseding it as the dominant form of social organization. ${ }^{99}$

Mid-century interpreters of Berle and Means, drew a considerably more sanguine set of conclusions from the managerial revolution, as we have seen. The separation of ownership and control in this view had led to greater democratization. But others, along with Berle and Means, saw more ominous implications.

The period from the 1950s into the 1980s saw a ferocious debate among American social scientists over the concentration of political power in the United States. Although the debate was complex, two primary views predominated, a pluralistic model and an elite model. In the former, power was seen as either widely dispersed or episodic. Occasionally, in this view, well-organized elites were able to achieve control, but only temporarily, until an organized opposition arose to knock them (through electoral means) from their pinnacle. In the elite model, power was viewed as concentrated among a unified, self-perpetuating group whose members were unaccountable to the majority. Occasionally, in this view, the masses were able to achieve certain victories, but these were seen as the exception rather than the rule.

In the early years of this debate, evidence accumulated on both sides. Pluralists showed in a series of studies that elites often did not get their way, ${ }^{100}$ and that they often fought one another. ${ }^{101}$ Elite theorists showed that members of a small group, with privileged social backgrounds, similar educational experiences, and both family and social connections, were disproportionately represented in important institutional positions. ${ }^{102}$ Although the early work within the elite perspective did not succeed in undermining the pluralist view, subsequent studies became increasingly sophisticated. A critical tenet of pluralism was the assumption of a divided elite. Even if a small group of elites dominates politically, as long as there is competition among them, the public can always replace the group that is in power with another segment of the elite. This, according to Schumpeter, Lipset, and other theorists of the period, was an important prerequisite for democracy. ${ }^{103}$ The studies of 
interlocks described above were attempts to address this question. As research by critics of pluralism multiplied, pluralists largely abandoned the area, although there were notable exceptions such as the important work by Laumann and Knoke, which used network analysis to move beyond a simple pluralist model. ${ }^{104}$ Meanwhile, advances within the elite tradition, both theoretical and empirical, continued. Useem argued that both pluralists and elite theorists were correct, but that each focused on a different level of analysis. ${ }^{105}$ When one looked at business as a whole, conflict was the rule, but when one considered only a small group of leaders of the largest firms - that is, individuals who spanned several firms simultaneously - this "inner circle" was capable of forging a unified position, Useem argued. Similarly, Whitt, in a study of several mass transportation initiatives in California, showed that although there were differences in interests and views among urban economic elites, organizations existed that allowed these elites to reach a unified position prior to lobbying the state. ${ }^{106}$

Building on these theories, I argued that the entire question of whether business was politically unified was misplaced. ${ }^{107}$ I suggested instead that business unity is a conditional phenomenon. Sometimes business is unified and sometimes it is not. The point, then, is to identify the conditions under which business unity and conflict occur. I found, in a study of political behavior among large U.S. corporations, that interfirm ties created by such factors as economic interdependence, common ownership, and director interlocks, were associated with the extent to which firms engaged in similar political behavior. Even this study, based on data from 1980, showed the prominent role of banks, however. Firms whose equity was held by the same institutional stockholders (primarily bank trust departments at the time) and that were indirectly interlocked through the same banks and insurance companies were significantly more likely to engage in similar political behavior than were firms without such ties.

The problem in more recent years, however, is that things appear to have changed. As we have seen, Davis and Mizruchi have documented the declining centrality of banks in the U.S. corporate interlock network. ${ }^{108}$ Few sociologists any longer write about the role of economic elites, or study such processes. ${ }^{109}$ U.S. firms (although not, as we have seen, U.S. banks) have become more global. The banks' political position within the business community has declined. Older, visible families such as the Rockefellers have disappeared. And yet we do not know what, if anything, has arisen in their places. 
Are there some accounts that we could apply to the contemporary situation? I mention here four possible arguments, and then offer a position of my own. The first, associated most prominently with Domhoff, suggests that the locus of power has changed little since the early-1980s. ${ }^{110}$ In this view, the U.S. economy is still dominated by a relatively small group of generally cohesive elites, perhaps less visible than in earlier years, but no less real. Instead of older, prominent families such as the Rockefellers and Mellons, Domhoff argues that the U.S. elite is now dominated by a later generation of individuals, most of whom continue to come from relatively privileged origins. The general character of the system, one in which this small group, through its business and policy organizations, advances its interests through infiltration and control of the state, remains intact.

A second view, advanced most prominently by Useem, suggests that institutional stockholders have become the dominant center of power in U.S. business. ${ }^{11}$ This is a result not only of the continued increase in their holdings over the past three decades but also because as the sizes of their holdings increase, the ability to display their dissatisfaction with corporate policy by selling their stock becomes more limited. As a consequence, Useem suggests, institutional investors have become increasingly active in attempting to influence corporate policies directly. Despite the potential power of these institutional investors, Useem makes no claim that they constitute a cohesive elite such as that described by Domhoff, or even the "inner circle" described by Useem himself in his earlier work. He acknowledges that some leading institutional investors represent long-standing, powerful, and connected firms such as Citigroup and Bankers Trust (although the latter, as of this writing, is owned by Deutsche Bank). Those who manage company pension funds are increasingly tied to professional rather than intra-class networks, however. ${ }^{112}$

A third, related argument has been suggested by Davis. ${ }^{113}$ Drawing on the Davis and Mizruchi study described above, ${ }^{114}$ Davis argues that there is no longer a single, identifiable group of dominant economic actors in the U.S. economy. Rather, pressures for both firms and the state to conform emanate directly from the capital market, whose influence has increased significantly since the early-1980s. The absence of a single dominant group does not mean that managers are autonomous. In fact, pressures from the capital market render managers less powerful today than during the heyday of managerialism in the 1950s and 
early-1960s, Davis argues. The difference is that there is now no single, consciously organized interest that oversees business as a whole in the way that, according to Mintz and Schwartz, the leading banks did. Not even institutional investors per se constitute such a group. Instead, corporate managers face pressure from an amorphous, but no less real, source. The implication is that this may leave them in an even more precarious situation than during the periods of family or bank control.

Finally, a number of scholars have suggested that with the increasing globalization of financial markets, national governments have lost the ability to regulate their own business communities. ${ }^{115}$ If these formulations are accurate, it would appear to follow that business elites have become increasingly intertwined over time, leading to the possible disappearance, or at least dispersion, of national corporate elites. There is some evidence that the discussions about the globalization of finance are exaggerated, both in terms of their magnitude (more than 80 percent of economic activity continues to take place within national boundaries) and in terms of their historical uniqueness (the proportion of economic activity across national boundaries in 1997, although considerably higher than in 1970, was approximately equal to the level in 1914). ${ }^{116}$ It is also unclear whether corporate elites at the turn of the twenty-first century have any greater power with respect to their states than their counterparts had in earlier decades. I cannot even begin to address this issue here. ${ }^{117}$ The degree of internationalization of the corporate elite is clearly an area that warrants greater scrutiny, however.

Drawing on these perspectives, I propose an argument of my own. Although the evidence for my claim is in no way conclusive, it allows for a suggestive portrait of the changes in the power and cohesiveness of the American business community over the past three decades. I argue that a paradoxical situation has emerged, in which individual firms have an increasing ability to pursue their narrow self-interest even to the point of engaging in illegal activity - while the business community as a whole is less able to act collectively, even when such coordination would be beneficial to the vast majority of firms.

From the postwar period well into the 1970 s, the U.S. business community, although pervaded by internal conflicts, remained relatively unified at the top. The presence of the inner circle, described by Useem in his earlier work, allowed leading members of the corporate elite to 
maintain a long-term outlook, in which they sought to forge a unified conception of the global interests of the business community. This group was supplemented by the major commercial banks, which shared an interest in mediating inter-firm disputes and protecting the long-term interests of business as a whole. Concurrent with this situation was the simultaneous existence of a relatively strong labor movement and an activist state, both of which enjoyed a high degree of legitimacy among business leaders and the larger public. The entire system was buttressed by a strong national economy.

As we moved into the 1970s, however, this arrangement began to crumble. Increasing foreign competition began to weaken major U.S. firms. The energy crisis triggered further economic instability, leading to the unprecedented coexistence of high levels of inflation and unemployment. Capital shortages increased the relative power of banks but weakened the system as a whole. By the late 1970s, U.S. business found itself in a relatively precarious position.

In response to this, the American business community launched a vigorous counteroffensive, a phenomenon that has been well documented. ${ }^{118}$ For the first time in decades, leading corporate interests began to attack the legitimacy of both labor unions, which were blamed for low productivity (and thus high inflation), and the interventionist state, which was blamed for excessive regulation that left U.S. firms unable to compete internationally. This counteroffensive culminated in the election of Ronald Reagan to the presidency and a shift, which has continued to the present, away from activist government toward a more laissez faire economic policy, now referred to as "neo-liberalism." Supported by sympathetic officials from the Reagan Administration, corporations now began a successful offensive against labor unions. The government, as David Vogel has noted, was so eager to serve the business community that firms in some cases received more than they had demanded. ${ }^{119}$

The upshot of these developments was that two of the key forces that had disciplined the business community and contributed to its longterm focus - labor and the state - were no longer viable. Meanwhile, as we moved into the 1980 s, commercial banks began their two-decade decline as arbiters of inter-industry disputes. The consequence of this was a paradoxical situation in which business appeared to lack any kind of unifying institution that would be the source of a long-term perspective, while at the same time its power seemed virtually unchallenged. This 
unchecked power, combined with the absence of disciplinary forces, either internal (the banks) or external (labor or the state), may have contributed to the excesses of the late-1990s and early-2000s, including the Enron scandal. If this account is correct, then individual firms are increasingly able to operate without the restraints, even from within the business community, that firms faced in earlier decades. A power vacuum thus exists at the top of the U.S. business community, a function, I would argue, of the decline of both the commercial banks and the inner circle.

My argument, of course, is only speculative at this juncture. Little evidence exists either in support of or opposition to it. But that is exactly my point: Because few sociologists are addressing questions about the nature of the U.S. corporate elite, the four preceding arguments, as well as mine, remain in the realm of supposition. What is needed to address these issues is a renewed attention to the study of corporate control: the ways in which this control affects, and is affected by, inter-firm relations; the structure of the corporate elite (including whether it makes sense even to treat the corporate elite as a distinct entity); and the nature of business political activity, including analysis of how such activity relates to the character of inter-firm relations.

\section{Conclusion}

It is clear, I hope, from this overview of the field, that much has been learned about corporate ownership and control and the structure of the business community, both in the United States and overseas. It is equally clear, however, that whatever was known about these topics over the past several decades, very little is known in more recent years. The question remains as to why the issue of corporate control and the structure of relations among firms should matter. For an answer, we have to return to Berle and Means. The corporation has undergone a number of transformations, and social scientists have had a difficult time developing theories to keep pace. Regardless of its changes in form, focus, ownership, and control, it remains a dominant institution in contemporary industrialized economies. Berle and Means were concerned about the corporation because of its power and its impact. Economists have every right to be concerned about ways to monitor management to increase and preserve shareholder 
value. Investors risk their capital when they invest in a firm, and they have a right to expect that those who represent them will be responsive to their concerns, in the same way that voters for political candidates do. But just as elected officials are not necessarily responsive to their constituents, corporate officials are not necessarily responsive to theirs. And whether we believe that corporations have a responsibility to the larger community, their actions affect that community nevertheless. The debates of the 1970s and 1980s did not resolve the question of the nature of corporate political power in capitalist societies. But at least social scientists were trying to answer the question. This topic no longer holds a central place in the fields of sociology and political science, yet there is no shortage of issues that cry out for attention.

It is unclear what new studies of corporate power will reveal. Corporations appear to be acting largely on their own, but they face pressures from stockholders, and the capital market in general, that managers did not face 25 years ago. Given the declining importance of banks, on the other hand, corporate managers may also have a degree of autonomy that their predecessors lacked. That corporate interests may exert increasing power in the electoral arena does not necessarily mean that corporate power as a whole is increasing. As Robert Dahl noted many years ago, for a group to be powerful requires not only resources, but also unity. ${ }^{120}$ Corporations pursuing their own interests, without an organized mobilization, may cancel each other out, as Dahrendorf and Galbraith suggested in an earlier era. ${ }^{121}$ On the other hand, evidence for the diffusion of corporate behavior across networks is large, and continues to grow, even based on contemporary data. What implications do these networks have for corporate political behavior? Is business mobilized at anything approaching its level in the late-1970s? Is business collective action less necessary now than it was then, because of the successes of the past? Can business be a powerful political actor simply by virtue of its structural position and the consequences, even inadvertent, that its behavior generates? Who benefits, and who loses, from scandals such as those that rocked the corporate world at the turn of the century? Can we identify, in specific terms, the role that the globalization of economic activity has played in domestic politics? Sociologists seem less concerned about issues of corporate control and power than they did two decades ago. The topic seems at least as worthy of attention now as it was then. 


\section{Acknowledgments}

An original draft of this article was presented at the conference on Shareholder-Value, Capitalism and Globalization, Bad Homburg, Germany, May 2001, sponsored by the Werner Reimers Foundation and the Volkswagen Foundation, for whose support I am grateful. A subsequent version was presented at the Annual Meeting of the American Sociological Association, Atlanta, August 2003. I would like to thank Charles Perrow, as well as the Theory and Society Editors and reviewers, for their comments and suggestions. ${ }^{122}$

\section{Notes}

1. Adolf A. Berle and Gardiner C. Means, The Modern Corporation and Private Property (New York: Harcourt, Brace \& World, [1932] 1968).

2. Rafael La Porta, Florencio Lopez-de-Silanes, and Andrei Shleifer, "Corporate Ownership Around the World," Journal of Finance 54 (1999): 471-517.

3. For an attempt at such a treatment, see Paul Windolf, Corporate Networks in Europe and the United States (Oxford: Oxford University Press, 2002).

4. Ralf Dahrendorf, Class and Class Conflict in Industrial Society (Stanford: Stanford University Press, 1959); John Scott, Corporations, Classes, and Capitalism (New York: St. Martin's Press, 1979).

5. For a comparative discussion of the relation between national financial systems and corporate control in France, Germany, Japan, and the U.K., see Linda Brewster Stearns and Mark S. Mizruchi, "Banking and Financial Markets" in Neil J. Smelser and Richard Swedberg, editors, Handbook of Economic Sociology, second edition (New York and Princeton: Russell Sage Foundation and Princeton University Press, in press).

6. Daniel Bell, The End of Ideology (New York: Collier, 1960); Dahrendorf, Class and Class Conflict; Talcott Parsons, Structure and Process in Modern Societies (New York: Free Press, 1960).

7. Joseph Schumpeter, Capitalism, Socialism, and Democracy (New York: Harper \& Row, 1942); Seymour Martin Lipset, "Introduction" in Robert Michels, Political Parties (New York: Free Press, 1962), 15-39.

8. Rudolf Hilferding, Finance Capital (Boston: Routledge \& Kegan Paul, [1910] 1981).

9. Pujo Committee [U.S. Congress, House Banking and Currency Committee], Investigation of Concentration and Control of Money and Credit (Washington: U.S. Government Printing Office, 1913); Louis D. Brandeis, Other Peoples' Money (New York: Frederick A. Stokes, 1914); Ida Tarbell, The History of the Standard Oil Company (New York: McClure, Phillips, 1905); Alexander Noyes, Forty Years of American Finance (New York: G.P. Putnam, 1909).

10. Mark J. Roe, Strong Managers, Weak Owners (Princeton: Princeton University Press, 1994).

11. Dahrendorf, Class and Class Conflict, 41.

12. David Riesman, The Lonely Crowd (Garden City, NY: Anchor, 1953), 242. 
13. Bell, The End of Ideology, 42.

14. Dahrendorf, Class and Class Conflict, 47. See also Talcott Parsons and Neil J. Smelser, Economy and Society (London: Routledge \& Kegan Paul, 1957), 254.

15. Carl Kaysen, "The Social Significance of the Modern Corporation," American Economic Review 47 (1957): 311-319.

16. For a discussion of the sales maximization hypothesis, see William J. Baumol, Business Behavior, Value, and Growth (New York: Macmillan, 1959). For a focus on the significance of growth, see John Kenneth Galbraith, The New Industrial State (New York: New American Library, 1967). For a model that deals with a number of possible managerial motives, see Robin L. Marris, The Economic Theory of Managerial Capitalism (London: Macmillan, 1964).

17. Dahrendorf, Class and Class Conflict, 46.

18. Peter M. Blau and Otis Dudley Duncan, The American Occupational Structure (New York: Free Press, 1967), 6.

19. R. Joseph Monsen, John S. Chiu, and David E. Cooley, "The Effect of Separation of Ownership and Control on the Performance of the Large Firm," Quarterly Journal of Economics 82 (1968): 435-451; John Palmer, "The Profit-Performance Effects of the Separation of Ownership from Control in Large United States Corporations," Bell Journal of Economics and Management Science 4 (1973): 293-303; David R. Kamerschen, "The Influence of Ownership and Control on Profit Rates," American Economic Review 58 (1968): 432-447.

20. Robert J. Larner, Management Control and the Large Corporation (New York: Dunellen, 1970).

21. David R. James and Michael Soref, "Profit Constraints on Managerial Autonomy: Managerial Theory and the Unmaking of the Corporation President," American Sociological Review 46 (1981): 1-18.

22. John Lintner, "The Financing of Corporations," in Edward S. Mason, editor, The Corporation in Modern Society (Cambridge: Harvard University Press, 1959), 166-201.

23. Linda Brewster Stearns, "Capital Market Effects on External Control of Corporations," Theory and Society 15 (1986): 47-75.

24. Oliver E. Williamson, The Economics of Discretionary Behavior: Managerial Objectives in a Theory of the Firm (Englewood Cliffs, NJ: Prentice-Hall, 1964); Herbert A. Simon, Administrative Behavior (New York: Macmillan, 1957).

25. Williamson, Markets and Hierarchies: Analysis and Antitrust Implications (New York: Free Press, 1975); Alfred D. Chandler, Jr., Strategy and Structure (Cambridge: MIT Press, 1962).

26. Chandler, The Visible Hand (Cambridge: Harvard University Press, 1977).

27. Michael C. Jensen and William H. Meckling, "Theory of the Firm: Managerial Behavior, Agency Costs, and Ownership Structure," Journal of Financial Economics 3 (1976): 305-360; Eugene F. Fama and Michael C. Jensen, "Separation of Ownership and Control," Journal of Law and Economics 26 (1983): 301-325.

28. Paul A. Baran and Paul M. Sweezy, Monopoly Capital (New York: Monthly Review Press, 1966).

29. Victor Perlo, The Empire of High Finance (New York: International Publishers, 1957).

30. Mayer N. Zald, "The Power and Function of Boards of Directors: A Theoretical Synthesis," American Journal of Sociology 75 (1969): 97-111. 
31. Peter C. Dooley, “The Interlocking Directorate," American Economic Review 59 (1969): 314-323.

32. Philip H. Burch, Jr., The Managerial Revolution Reassessed (Lexington, MA: D.C. Heath, 1972).

33. Maurice Zeitlin, "Corporate Ownership and Control: The Large Corporation and the Capitalist Class," American Journal of Sociology 79 (1974): 1073-11 19.

34. Larner, Management Control.

35. Robert J. Sheehan, "Proprietors in the World of Big Business," Fortune (June 15, 1967): 178-183, 242.

36. Paul M. Sweezy, "The Decline of the Investment Banker," Antioch Review 1 (1942): 63-68; Perlo, The Empire of High Finance.

37. See Michael Useem, Investor Capitalism (New York: Basic Books, 1996).

38. David M. Kotz, Bank Control of Large Corporations in the United States (Berkeley: University of California Press, 1978).

39. Berle and Means, The Modern Corporation, 66.

40. Maurice Zeitlin and Richard E. Ratcliff, Landlords and Capitalists: The Dominant Class of Chile (Princeton: Princeton University Press, 1988).

41. Lewis Corey, The House of Morgan (New York: G. Howard Watt, 1930), 284.

42. Ibid. John Scott, in a study of the late twentieth century United States, U.K., and other European nations, reached a similar conclusion, suggesting that control was achieved through a "constellation of interests." See Scott, Corporations, Classes, and Capitalism (New York: St. Martin's Press, 1979).

43. Gerald F. Davis and Michael Useem, "Top Management, Company Directors, and Corporate Control" in Andrew Pettigrew, Howard Thomas, and Richard Whittington, editors, Handbook of Strategy and Management (London: Sage Publications, 2002).

44. See, for example, Joseph E. Stiglitz, "Credit Markets and the Control of Capital," Journal of Money, Credit, and Banking 17 (1985): 133-152; Randall S. Kroszner and Philip E. Strahan, "Bankers on Boards: Monitoring, Conflicts of Interest, and Lender Liability," Journal of Financial Economics 62 (2001): 415-452; Benjamin E. Hermalin and Michael S. Weisbach, "Boards of Directors as an Endogenously Determined Institution: A Survey of the Economic Literature," Economic Policy Review 9 (2003): 7-26.

45. The Modern Corporation, 196.

46. Ibid., 66.

47. For a review of this literature, see Mark S. Mizruchi, "What Do Interlocks Do? An Analysis, Critique, and Assessment of Research on Interlocking Directorates," Annual Review of Sociology 22 (1996): 271-298.

48. Louis D. Brandeis, Other Peoples' Money (New York: Frederick A. Stokes, 1914).

49. The Sherman Antitrust Law of 1890 prohibited anti-competitive activity among U.S. firms.

50. Brandeis, Other Peoples' Money, 35.

51. Arnold M. Rose, The Power Structure (New York: Oxford University Press, 1967), 133.

52. Ibid., 92.

53. C. Wright Mills, The Power Elite (New York: Oxford University Press, 1956); Rose, The Power Structure.

54. See, for example, Peter Mariolis, "Interlocking Directorates and Control of Corporations: The Theory of Bank Control," Social Science Quarterly 56 (1975): 
425-439; Beth Mintz and Michael Schwartz, The Power Structure of American Business (Chicago: University of Chicago Press, 1985); Mark S. Mizruchi, The American Corporate Network, 1904-1974 (Beverly Hills: Sage Publications, 1982).

55. The above quote from Brandeis implies that investment bankers controlled not only railroads and industrial corporations but also commercial banks and insurance companies. In the early 1900 s, the leading investment bankers, most notably J.P. Morgan, were seen as exercising control over a range of corporations, often through their control of banks and insurance companies. At the time, investment banks were especially powerful because they could hold deposits and therefore fulfill the functions of commercial banks. The Glass-Steagall Act of 1933 required investment and commercial banks to separate their functions. Investment banks, forced to give up their deposits, lost their primary source of capital, and, according to a number of observers, their power. Even those who argued that financial power continued in the decades following Glass-Steagall therefore focused on commercial banks and insurance companies. In the 1990s, faced with increasing competition from foreign banks, U.S. commercial banks increasingly took on the functions of investment banks. The U.S. Congress overturned the Glass-Steagall Act in 1999. For a discussion of the changing roles of commercial and investment banks during the 1930s, see Mizruchi, The American Corporate Network.

56. Duncan J. Watts, Small Worlds: The Dynamics of Networks Between Order and Randomness (Princeton: Princeton University Press, 1999).

57. For illustrations of this point, see Karen S. Cook and Joseph M. Whitmeyer, "Two Approaches to Social Structure: Exchange Theory and Network Analysis," Annual Review of Sociology 18 (1992): 109-127; Mark S. Mizruchi and Blyden B. Potts, "Centrality and Power Revisited: Actor Success in Group Decision Making," Social Networks 20 (1998): 353-387.

58. Myles L. Mace, Directors: Myth and Reality (Boston: Harvard Business School Press, 1971), 73.

59. Mizruchi, The American Corporate Network.

60. There was some evidence that bankers tended to join the boards of firms experiencing declining profits. For two examples see R. Jack Richardson, "Directorship Interlocks and Corporate Profitability," Administrative Science Quarterly 32 (1987): 367-386, and Mark S. Mizruchi and Linda Brewster Stearns, "A Longitudinal Study of the Formation of Interlocking Directorates," Administrative Science Quarterly 33 (1988): 194-210. In a study based on data from 1992, however, Kroszner and Strahan found that bankers tended to sit on the boards of large, well-performing firms. This may reflect a change in bank behavior over time. See Randall S. Kroszner and Philip E. Strahan, "Bankers on Boards: Monitoring, Conflicts of Interest, and Lender Liability," Journal of Financial Economics 62: 415-452. See also Gerald F. Davis and Mark S. Mizruchi, "The Money Center Cannot Hold: Commercial Banks in the U.S. System of Corporate Governance," Administrative Science Quarterly 44 (1999): 215-239.

61. Mintz and Schwartz, The Power Structure of American Business.

62. Jay W. Lorsch and Elizabeth MacIver, Pawns or Potentates: The Reality of America's Corporate Boards (Boston: Harvard Business School Press, 1989).

63. Jeffrey Pfeffer and Gerald R. Salancik, The External Control of Organizations: A Resource Dependence Perspective (New York: Harper \& Row, 1978). A 
paperback edition of the book, with a valuable new introduction, has recently been published by Stanford University Press, 2003.

64. Three studies from the late 1970s and early 1980s indicated that interlocks between firms that were accidentally broken, through death or retirement of the director, were replaced in only a small minority of cases. This raised further questions about whether interlocks reflected control relations between firms. See Thomas Koenig, Robert Gogel, and John Sonquist, "Models of the Significance of Interlocking Corporate Directorates," American Journal of Economics and Sociology 38 (1979): 173-186; Michael D. Ornstein, "Assessing the Meaning of Corporate Interlocks: Canadian Evidence," Social Science Research 9 (1980): 287-306; Donald Palmer, "Broken Ties: Interlocking Directorates, and Intercorporate Coordination,” Administrative Science Quarterly 28 (1983): 40-55.

65. Mark S. Mizruchi, "Who Controls Whom? An Examination of the Relation Between Management and Boards of Directors in Large American Corporations," Academy of Management Review 8 (1983): 426-435.

66. Robert A. Dahl, "A Critique of the Ruling Elite Model," American Political Science Review 52 (1958): 463-469; Nelson W. Polsby, "How to Study Community Power: The Pluralist Alternative," in Michael Aiken and Paul Mott, editors, The Structure of Community Power (New York: Random House), 297-304.

67. For an exceptionally clear presentation of this position, see Steven Lukes, Power: A Radical View (New York: Macmillan, 1974).

68. Peter Bachrach and Morton S. Baratz, "The Two Faces of Power," American Political Science Review 56 (1962): 947-952.

69. Mills, The Power Elite.

70. Mace, Directors: Myth and Reality, 124.

71. Douglas Bauer, "Why Big Business is Firing the Boss," New York Times Magazine (March 8, 1981): 22-25, 79-91.

72. James and Soref, "Profit Constraints on Managerial Autonomy."

73. The scandals at Enron and other U.S. companies at the turn of the twenty-first century appear to call into question the board's ability to monitor management. Similar cases have occurred in earlier years, most notably the bankruptcy of the Penn Central Railroad in 1970, when Penn Central's board members were lulled, by management and its accountants, into believing that the company was on a strong financial footing. At this writing we do not know the extent to which Enron's board members were aware of the accounting improprieties allegedly perpetrated by CEO Kenneth Lay and the firm's auditor, Arthur Andersen \& Co., although the board has denied any knowledge of them. These events illustrate, as agency theorists suggest, that the board's monitoring of management is always problematic and cannot be taken for granted. They do not by themselves indicate that boards are incapable of such monitoring, however. Moreover, the fact that the Enron episode occurred when it did is actually consistent with the argument presented here. When the economy is strong and firms are performing well, the board has less need to monitor management, and managers may find it easier to take liberties in ways that they would not otherwise be able to do. It is possible, and perhaps even likely, that significant numbers of similar kinds of actions were taking place during the boom of the late-1990s, many of which did not come to the surface because companies continued to perform well. Once the boom ended, it was no longer possible to hide such behavior, and managers again became 
vulnerable, although as in the Enron case, boards did not always react in time to save the firm.

74. James W. Fredrickson, Donald C. Hambrick, and Sara Baumrin, "A Model of CEO Dismissal," Academy of Management Review 13 (1987): 255-270.

75. Barry Baysinger and Robert E. Hoskisson, "The Composition of Boards of Directors and Strategic Control: Effects on Corporate Strategy," Academy of Management Review 15 (1990): 72-87; James P. Walsh and James K. Seward, "On the Efficiency of Internal and External Corporate Control Mechanisms," Academy of Management Review 15 (1990): 421-458.

76. Mizruchi, "What Do Interlocks Do?"

77. Rita D. Kosnik, "Greenmail: A Study of Board Performance in Corporate Governance," Administrative Science Quarterly 32 (1987): 163-185.

78. Philip L. Cochran, Robert A. Wood, and Thomas B. Jones, "The Composition of Boards of Directors and Incidence of Golden Parachutes," Academy of Management Journal 28 (1985):664-671; Harbir Singh and Farid Harianto, "Management-Board Relationships, Takeover Risk, and the Adoption of Golden Parachutes," Academy of Management Journal 32 (1989): 7-24.

79. James Wade, Charles A. O'Reilly, III, and Ike Chandratat, "Golden Parachutes: CEOs and the Exercise of Social Influence," Administrative Science Quarterly 35 (1990): 587-603.

80. Other relevant studies of board structure and behavior include Edward J. Zajac and James D. Westphal, "Director Reputation, CEO-board Power, and the Dynamics of Board Interlocks," Administrative Science Quarterly 41 (1996): 507-529; James D. Westphal and Edward J. Zajac, "Defections from the Inner Circle: Social Exchange, Reciprocity, and the Diffusion of Board Independence in U.S. Corporations," Administrative Science Quarterly 42 (1997): 161-183; Albert A. Cannella, Jr. and Wei Shen, "So Close and Yet So Far: Promotion versus Exit for CEO Heirs Apparent," Academy of Management Journal 44 (2001): 252-270. Three additional works demonstrate that the structure of a firm's board influences the level and type of financing it receives. See Linda Brewster Stearns and Mark S. Mizruchi, "Board Composition and Corporate Financing: The Impact of Financial Institution Representation on Borrowing," Academy of Management Journal 36 (1993): 603-618; Mark S. Mizruchi and Linda Brewster Stearns, "A Longitudinal Study of Borrowing by Large American Corporations," Administrative Science Quarterly 39 (1994): 118-140; Daniel T. Byrd and Mark S. Mizruchi, "Bankers on the Board and the Debt Ratio of Firms," Journal of Corporate Finance (in press).

81. Gerald F. Davis, "Agents Without Principles? The Spread of the Poison Pill through the Intercorporate Network," Administrative Science Quarterly 36 (1991): 583-613.

82. Pamela R. Haunschild, "Interorganizational Imitation: The Impact of Interlocks on Corporate Acquisition Activity," Administrative Science Quarterly 38 (1993): 564-592.

83. Mark S. Mizruchi, "Similarity of Political Behavior Among Large American Corporations," American Journal of Sociology 95 (1989): 401-424.

84. Donald Palmer, Brad M. Barber, Xueguang Zhou, and Yasmin Soysal, "The Friendly and Predatory Acquisition of Large U.S. Corporations in the 1960s: The Other Contested Terrain," American Sociological Review 60 (1995): 469-499. See also Donald Palmer and Brad M. Barber, "Challengers, Elites, 
and Owning Families: A Social Class Theory of Corporate Acquisitions in the 1960s," Administrative Science Quarterly 46 (2001): 87-120.

85. Gerald F. Davis and Suzanne K. Stout, "Organization Theory and the Market for Corporate Control: A Dynamic Analysis of the Characteristics of Large Takeover Targets, 1980-1990," Administrative Science Quarterly 37 (1992): 605-633; Neil Fligstein and Peter Brantley, "Bank Control, Owner Control, or Organizational Dynamics: Who Controls the Large Modern Corporation?" American Journal of Sociology 98 (1992): 280-307; Neil Fligstein and Linda Markowitz, "Financial Reorganization of American Corporations in the 1980s," in William Julius Wilson, editor, Sociology and the Public Agenda (Newbury Park, CA: Sage Publications, 1993), 185-206.

86. Useem, Investor Capitalism.

87. Davis and Useem, "Top Management, Company Directors, and Corporate Control."

88. Hilferding, Finance Capital; V.I. Lenin, Imperialism: The Highest Stage of Capitalism (Peking [Beijing]: Foreign Languages Press, [1917] 1975).

89. Kotz, Bank Control of Large Corporations.

90. Robert Fitch and Mary Oppenheimer, "Who Rules the Corporations?" Socialist Revolution 1 (1970) (4): 73-108; (5): 61-114; (6): 33-94.

91. Paul M. Sweezy, "The Resurgence of Financial Control: Fact or Fancy?" in Sweezy and Harry Magdoff, The Dynamics of U.S. Capitalism (New York: Monthly Review Press, 1972); James O'Connor, "Question: Who Rules the Corporations? Answer: The Ruling Class," Socialist Revolution 7 (1972): 117150 .

92. Edward S. Herman, Corporate Control, Corporate Power (New York: Cambridge University Press, 1981).

93. Mintz and Schwartz, The Power Structure of American Business.

94. Stiglitz, "Credit Markets and the Control of Capital."

95. Davis and Mizruchi, "The Money Center Cannot Hold."

96. Mark S. Mizruchi and Gerald F. Davis, "The Globalization of American Banking, 1962-1981," in Frank Dobbin, editor, The Sociology of the Economy (New York: Russell Sage Foundation, 2004), 95-126.

97. Mark S. Mizruchi and Linda Brewster Stearns, "Getting Deals Done: The Use of Social Networks in Bank Decision-Making," American Sociological Review 66 (2001): 647-671.

98. Davis and Mizruchi, "The Money Center Cannot Hold."

99. Berle and Means, The Modern Corporation, 313.

100. Robert A. Dahl, Who Governs? (New Haven: Yale University Press, 1961).

101. Raymond A. Bauer, Ithiel de Sola Pool, and Lewis Anthony Dexter, American Business and Foreign Policy: The Politics of Foreign Trade (New York: Atherton Press, [1963] 1972).

102. G. William Domhoff, Who Rules America? (Englewood Cliffs, NJ: Prentice-Hall, 1967); Peter Freitag, "The Cabinet and Big Business: A Study of Interlocks," Social Problems 23 (1975): 137-152.

103. Schumpeter, Capitalism, Socialism, and Democracy; Lipset, "Introduction," in Michels, Political Parties.

104. Edward O. Laumann and David Knoke, The Organizational State (Madison: University of Wisconsin Press, 1987).

105. Michael Useem, The Inner Circle (New York: Oxford University Press, 1984). 
106. J. Allen Whitt, Urban Elites and Mass Transportation (Princeton: Princeton University Press, 1982). See also Dan Clawson, Alan Neustadtl, and Denise Scott, Money Talks: Corporate PACs and Political Influence (New York: Basic Books, 1992).

107. Mark S. Mizruchi, The Structure of Corporate Political Action: Interfirm Relations and their Consequences (Cambridge: Harvard University Press, 1992).

108. Davis and Mizruchi, "The Money Center Cannot Hold."

109. For exceptions, see Michael C. Dreiling, "The Class Embeddedness of Corporate Political Action: Leadership in Defense of the NAFTA," Social Problems 47 (2000): 21-48; Harland Prechel, Big Business and the State: Historical Transitions and Corporate Transformation, 1880s-1990s (Albany: State University of New York Press, 2000); Val Burris, "The Two Faces of Capital: Corporations and Individual Capitalists as Political Actors," American Sociological Review 66 (2001): 361-381.

110. G. William Domhoff, Who Rules America? Power and Politics in the Year 2000 (Mountain View, CA: Mayfield, 1998).

111. Useem, Investor Capitalism.

112. Useem, Investor Capitalism, 267-269.

113. Gerald F. Davis, "Financial Markets and Classes in Late Capitalism," paper presented at the Annual Meeting of the Academy of Management (Chicago, 1999).

114. Davis and Mizruchi, "The Money Center Cannot Hold."

115. Jeffry Frieden, "Invested Interests: The Politics of National Economic Policies in a World of Global Finance," International Organization 45 (1991): 425-451; Susan Strange, The Retreat of the State (Cambridge: Cambridge University Press, 1996); Philip G. Cerny, "International Finance and the Erosion of Capitalist Diversity," in Colin Crouch and Wolfgang Streeck, editors, Political Economy of Modern Capitalism (London: Sage Publications, 1997), 173-181.

116. See Neil Fligstein, The Architecture of Markets (Princeton: Princeton University Press, 2001).

117. For a recent comparative analysis of interfirm networks in the United States and Europe, see Paul Windolf, Corporate Networks in Europe and the United States (Oxford: Oxford University Press, 2002).

118. See, among others, J. Craig Jenkins and Craig Eckert, "The Corporate Elite, The New Conservative Policy Network, and Reaganomics," Critical Sociology 16 (1989) (2-3): 121-144; David Vogel, Fluctuating Fortunes: The Political Power of Business in America (New York: Basic Books, 1989).

119. Vogel, Fluctuating Fortunes.

120. Dahl, "A Critique of the Ruling Elite Model."

121. Dahrendorf, Class and Class Conflict in Industrial Society; John Kenneth Galbraith, American Capitalism (Boston: Houghton Mifflin, 1952).

122. Please direct correspondence to Mark Mizruchi, Department of Sociology, University of Michigan, 1225 S. University Ave., Ann Arbor, MI, 48104-2590, phone (734) 764-7444, e-mail: mizruchi@umich.edu. 